\title{
Analysis of Student Expertise Examination Policy Based on Computer Based Assessment at the Center of Educational and Training Cruise Malahayati Aceh Indonesia
}

\author{
Moch. Yusup \\ BP2IP Malahayati Aceh \\ Aceh Besar, Indonesia \\ profcut@unsyiah.ac.id
}

\author{
Cut Zahri Harun \\ Department of Educational Administration \\ Syiah Kuala University, Indonesia \\ profcut@unsyiah.ac.id
}

\author{
Sakdiah Ibrahim \\ Department of Educational Administration \\ Syiah Kuala University, Indonesia \\ profcut@unsyiah.ac.id
}

\begin{abstract}
Evaluation of learning outcomes is an indicator of the quality of education of an educational institution, including at Balai Pendidikan dan Pelatihan Ilmu Pelayaran (BP2IP) Malahayati Aceh. As technology advances, learning evaluation is carried out by Computer Based Assessment (CBA), it is expected that with the application of CBA, evaluation can be carried out transparently and systemically. This research was conducted using a policy evaluation method of the Seafarers Expertise (UKP) at BP2IP Malahayati Aceh. Research uses a qualitative approach. Subjects in the study included the head of BP2IP Malahayati Aceh, PUKP 01 - Medan and Aceh administrators, instructors / teachers, and students. Data collection is done by structured interviews, observation and documentation. Data analysis techniques through data reduction, data presentation and verification. The results of the study show that (1) the implementation of CBA-based UKP refers to the Dirjen Hubla's policy, through the Regulation of the Director General of Sea Transportation No. HK. 103/4/2 / DJPL-2015 concerning the System and Procedure for the Implementation of UKP and the Seafarers Expertise Examination Board Letter (DPKP) No. DPKP / UM / 230 / VIII / 17 concerning UKP Implementation Guidelines using CBA (Computer Based Assessment); (2) the implementation of CBA-based UKP in BP2IP Malahayati Aceh is classified as smooth and good and effective. This is known from the variables of policy implementation, namely communication, resources, disposition and bureaucratic structures that are well implemented; (3) The implementation of CBA-based UKP policy in BP2IP Malahayati Aceh provides positive and negative impacts for training participants.
\end{abstract}

Keywords: computer based assessment, policy analysis, seafarers expertise tests

\section{INTRODUCTION}

Education is the process of forming intellectual and emotional fundamental skills which is an effort to develop useful and quality human qualities for the advancement of the nation and state. In order to improve the quality of education, the participation and support of all relevant parties is needed both from the school, community, and government.

Education in Indonesia both formal and nonformal education is expected to produce qualified graduates who are recognized at national and international levels and graduates have the knowledge, skills and personal character and character that are reliable and acceptable in the world of work. Without producing qualified graduates, education programs are not a long-term investment of human resources, but only a waste both in terms of cost, energy, time, and will cause various social problems.

In order to control the quality of education nationally it has been regulated in Law Number 20 of 2003 concerning the National Education System (Sisdiknas) article 57 paragraph 1 which states that Evaluation is carried out in order to control the quality of education nationally as a form of accountability of education providers to parties interested party. Furthermore, Article 57 paragraph 2 states that Evaluation is carried out on students, institutions and educational programs on formal and non-formal education pathways for all levels, units and types of education.

\section{METHODS}

This study aims to find out how the implementation of policies and the impact of seafarers' expertise tests based on Computer Based Assessment at BP2IP Malahayati Aceh. The research approach used is a qualitative approach, because research problems are considered unclear, still dim or maybe still dark. Sugiyono (2015) Qualitative research is the process of exploring and understanding the meaning of individual and group behavior, describing social problems or humanitarian problems. The research process includes making research questions and procedures that are still temporary, collecting data on participant settings, inductive data analysis, build partial data into themes, and then provide an interpretation of the meaning of a data.The final activity is to make a report into a flexible structure

Subjects in the study or respondents, consisting of the head Balai Pendidikan dan Pelatihan Ilmu Pelayaran (BP2IP) Malahayati Aceh, Board PUKP 01 - Medan and Aceh, instructors / teachers, and the students / examinees membership of the sailors. in accordance with the form of qualitative research as well as the type of data source used, then the data collection techniques that will be used in the research 
is a structured interview, observation, and documentation Satori and Komariah (2014) The process of analyzing qualitative data is carried out since before entering the field, during the field, and after completion in the field. Data analysis in qualitative research, carried out by reduction, data presentation, and conclusion drawing / verification.

\section{RESULTS}

Background of the Sailors Expertise Based on Computer Based Assessment Policy at BP2IP Malahayati Aceh

Development of CBA-based seafarers expertise test exams must be assessed through education policies. Solichin (2015) Educational policy is a formulation of various ways to realize the goals of national education, realized or achieved through social institutions or social organizations in the form of formal, non-formal, and informal educational institutions. The implementation of the CBA-based seafaring expertise test refers to the policy issued by the Director General of Hubla, namely through the Director General of Sea Transportation Regulation No. HK. 103/4/2 / DJPL-2015 concerning the System and Procedure for the Implementation of the Seafarers Expertise Examination and the Seafarers' Expertise Board of Examination Letter (DPKP) No. DPKP / UM / 230 / VIII / 17 concerning UKP Implementation Guidelines using CBA (Computer Based Assessment).

The policy discusses the procedures, technical instructions and mechanisms for the implementation of CBA-based seafaring skills exams. Every policy formulated is expected to realize the goals and objectives that have been determined. The objectives behind the holding of CBA-based seafaring skills exams include more reliable, faster, and more efficient implementation, minimizing the costs incurred for seafarers expertise test activities, and more fair and accountable to training participants, DPKP, and Training centers.

Policy Implementation Seafarers Expertise Based on Computer Based Assessment in BP2IP Malahayati Aceh

Based on the results of the research on the implementation of the CBA-based seafarers expertise test in BP2IP Malahayati Aceh, 4 (four) variables were used, namely communication, resources, disposition, and bureaucratic structure. Communication variables in the implementation of the policy went well, it can be seen the process of channeling and clarity of communication carried out well without going through a long bureaucracy, orders are carried out in writing and are technical and the implementers have special skills and abilities so that the commands / instructions are well understood . In addition, information / orders that have been set do not change frequently and are equipped with clear procedures so as to eliminate the choice of multi interpreters and have a detailed reporting mechanism.

The second variable is the resource, the resource has three indicators, namely the number / adequacy, expertise and ability of staff, the authority or authority for the implementer and the availability of facilities / facilities has been fulfilled properly so that the implementation can run effectively. The third variable is disposition, there are 2 (two) indicators of disposition, namely the level of commitment and democratic level. Based on the results of the study that indicators of the level of commitment and honesty from the implementation of CBA-based seafarers' expertise test activities which include provisions on facilities and infrastructure, UKP implementation procedures using CBA which includes UKP management standards using CBA, UKP materials using CBA and UKP graduation criteria using CBA as a whole is carried out consistently according to what has been stipulated by the DPKP through the letter of the Seafarers Expertise Testers Board (DPKP) No. DPKP / UM / 230 / VIII / 17 concerning UKP Implementation Guidelines using CBA (Computer Based Assessment). The second indicator of disposition is the democratic level of the implementers, the intensity of sharing (exchanging opinions) between the DPKP and the PUKP is routinely carried out, both through meeting forums held in the DPKP by inviting PUKP members throughout the regions in Indonesia, the process of delivering opinions can also be carried out every evaluation of implementation CBA seafarers expertise test, and at the time of the hearing the determination of graduation of the CBA-based seafaring skills exam. Submission of these obstacles as input to the DPKP so that solutions can be sought from the problems faced and do different discretion with instructions to achieve the goals and objectives of the program.

The fourth variable is the bureaucratic structure, the main indicator of the bureaucratic structure is the existence of standard work procedures / Standard Operational Procedures (SOP) and fragmentation. Based on the results of the research that the SOP for the implementation of the CBA-based seafarers expertise test was made in a simple manner, the implementers already had standard work procedures in carrying out the policy. Fragmentation or dissemination of responsibilities related to $\mathrm{CBA}$ seafarers expertise test policies is carried out without overlapping but the spread of tasks is carried out thoroughly in implementing policies.

\section{Impact of Seafarers Expertise Examination Policy Implementation Based on Computer Based Assessment at BP2IP Malahayati Aceh}

Although the test using CBA has more advantages over using PBT exams, in technical matters there are still perceived obstacles or obstacles, especially in terms of classifying types of exam questions and language usage English in exam questions. These two things were felt by the participants which caused the failure in this CBAbased seafarers expertise test. From the results of this study, the authors conclude that the objectives of the CBA-based seafaring expertise test are to be the right measuring tool for evaluating the competencies of students in marine education and training institutions in accordance with the minimum competency standards 
for each level of diploma set in STCW (Standard of Training and Certification of Watchkeeping for Seafarers) 1978 and its amendments have not been fully achieved.

\section{DISCUSSION}

Also explained in Law Number 20 of 2003 concerning the National Education System (Sisdiknas) article 58 paragraph 1 that Evaluation of learning outcomes of students is carried out by educators to monitor the process, progress and improvement of learning outcomes of students on an ongoing basis. Then in article 58 paragraph 2 states Evaluation of students, education units and education programs is carried out by independent institutions periodically, comprehensively, transparently and systemically to assess the achievement of national education standards.

The process of evaluating the results of students of educational institutions within the Ministry of Transportation, including the Balai Pendidikan dan Pelatihan Ilmu Pelayaran (BP2IP), Malahayati Aceh, is called the Seafarers Expertise Examination, which is a system of assessing the level of ability and ability of marine exam participants in mastering the marine professional field to obtain seafarers expertise certificates. and or an inaugural certificate carried out by the Seafarers Expertise Test Board (DPKP) which is responsible to the Director General of Sea Transportation.

Based on the Director General of Sea Transportation Regulation No. HK. 103/4/2 / DJPL-2015 concerning the System and Procedure for the Implementation of the Seafarers 'Expertise Examination and the Seafarers' Expertise Board of Examination Letter (DPKP) No. DPKP / UM / 230 / VIII / 17 concerning UKP Implementation Guidelines using CBA (Computer Based Assessment) that the implementation of seafarers' expertise tests using CBA (Computer Based Assessment) began to take place on July 3, 2017.

The use of CBA in the implementation of seafarers expertise tests caused many problems, such as classification of questions based on function / competency not based on subjects so that students find it difficult to identify problems, seafarers 'skills exam questions are often deemed not in accordance with the curriculum, types of seafarers' expertise test using English, resulting in examiners the expertise of many sailors who did not graduate.

\section{CONCLUSION}

The implementation of the CBA-based seafaring expertise test refers to the policy issued by the Director General of Hubla, through the Regulation of the Director General of Sea Transportation No. HK. 103/4/2 / DJPL-2015 concerning the System and Procedure for the Implementation of the Seafarers Expertise Examination and the Seafarers Expertise Board of Examination Letter (DPKP) No. DPKP / UM / 230 / VIII / 17 concerning UKP Implementation Guidelines using CBA (Computer Based Assessment). The policy discusses procedures, technical guidelines and mechanisms for implementing CBA-based UKP.
The implementation of the CBA-based seafarers expertise test at BP2IP Malahayati Aceh has been classified as smooth and good and effective. This is known from variables to assess policy implementation, namely communication, resources, disposition and bureaucratic structures that have been fulfilled and implemented properly.

The implementation of the CBA-based seafaring expertise test policy at BP2IP Malahayati Aceh has a positive and negative impact on training participants: (1) the positive impact of policy implementation is the shorter test time, the ease of work on the questions, the questions can be randomized automatically by the system, so as to reduce the chance of the exam participants doing fraud, and the security or confidentiality of guaranteed exam questions so that they are more accountable; and (2) the negative impact of policy implementation is the passing of participants on CBA-based seafarers skills examinations on average below $50 \%$ of all participants who take the exam in one period.

\section{REFERENCES}

[1] Satori, D., and Komariah, A. 2014. Qualitative Research Methods. Bandung: Alfabeta.

[2] Solichin, M. 2015. Implementation of Education Policy and the Role of Bureaucracy. Journal of Islamic Studies, 6(2), 148-178.

[3] Sugiyono. 2015. Easy Way to Compile Thesis, Thesis and Dissertation (STD). Bandung: Alfabeta.

[4] Republic of Indonesia Law Number 20 of 2003 National Education System. 2014. Jakarta: Ministry of Education and Culture. 